\title{
The 2008 Helene Hudson Memorial Lectureship
}

\section{Supporting children of parents who are dying}

by Katrina Longfield and Andrea Warnick

\section{Abstract}

Nurses, parents and other family members tend to feel ill equipped when talking to children about a parent's impending death. Adults often feel the need to protect children from the reality of a parent's imminent death. However, research indicates that children experience increased levels of anxiety when information regarding a parent's terminal prognosis is withheld from them. As a result, not telling children that their parent is dying does not avert a fearful situation for the child but, rather, it denies the child access to accurate information and appropriate emotional support. Oncology nurses are uniquely placed to provide guidance to parents on this topic. This paper will include a nursing narrative and practical strategies for communicating with children whose parents are dying.

\section{Introduction}

The authors would like to thank Amgen for sponsoring this lectureship in memory of Helene Hudson. It is an honour to have the opportunity to shed light on this topic in memory of a nurse, Helene Hudson, who made such significant contributions to the field of oncology nursing.

Telling a child that a parent will die from his or her cancer is a conversation that no parent, nor nurse, wants to have. It is a dialogue for which few people have received any type of formal training, regardless of their professional background. Yet, it is not uncommon for oncology nurses to be caring for a dying parent who requires guidance in having just such a conversation. At times, the nurse is expected to take the lead in notifying a child of a parent's impending death.

The manner in which a child learns of a parent's dying, and the way in which he/she is subsequently supported, can have a significant impact on the child's bereavement process. Thus, it is important for oncology nurses to develop an ability to talk to the children of a parent who is dying and to provide guidance to parents on how to support their children through a death in the family.

\section{Literature review}

Many factors contribute to nurses feeling reluctant to initiate conversations regarding a parent's impending death. Health care professionals may feel a strong need to protect children and may believe that the child is too young to know or that they will not be able to cope with the news that their parent is dying (Riley, 2003; Smith, 1995). However, the research indicates that a child's level of anxiety is significantly lowered if they are kept informed about their parent's illness and impending death (Kroll, Barnes, Jones \& Stein, 1998; MacPherson, 2005).

Nurses also need to be aware of the fact that parents are often unaware of their child's level of anxiety and distress related to the illness of the parent (Welch, Wadsworth, \& Compass, 1996). Thus, health care professionals may need to assist parents in recognizing and coping with their children's distress when it is present.
It is essential to remember that just because adults are not talking to the child about the parent's illness and dying process does not mean that children are unaware of what is happening in the family. Children are extremely observant of the world around them, so when adults attempt to protect them from the reality of dying and death by not talking to them about it, what they are actually doing is leaving children to come up with their own explanations about what is happening around them (Riley, 2003; Robinson \& Janes, 2001; Silverman, 2000). The child of a parent who is dying will most certainly have noticed the changes that the illness has wrought upon her/his parent. If the child is kept away from the parent while they are actively dying, the child will often imagine dying to look worse than it actually is (Riley, 2003). In addition, open communication with

\section{Prix de conférence à la mémoire de Helene Hudson 2008 \\ Donner du soutien aux enfants dont un parent est mourant}

\section{Abrégé}

Les infirmières, les parents et les autres membres de la famille estiment souvent qu'ils n'ont pas les compétences nécessaires pour parler aux enfants du décès imminent d'un de leurs parents. Les adultes éprouvent généralement le besoin de protéger les enfants de la pénible réalité qu'un tel décès représente. Toutefois, la recherche indique que les enfants connaissent des niveaux accrus d'anxiété lorsque l'information concernant le très sombre pronostic de vie du parent concerné ne leur est pas communiquée. Par conséquent, le fait de ne pas apprendre à un enfant que son parent se meurt n'évite pas à l'enfant de vivre une situation effrayante; au contraire, cela l'empêche d'accéder à une information exacte et à un soutien émotionnel approprié. Les infirmières en oncologie occupent une position idéale pour conseiller les parents dans ce domaine. Le présent article comprend une étude de cas en soins infirmiers et des stratégies pratiques pour communiquer avec l'enfant dont un des parents est sur le point de mourir.

La traduction de cette article est sur la site Web de l'ACIO.

Katrina J. Longfield, RN, BScN, Palliative Care Staff Nurse, Princess Margaret Hospital, Toronto, Ontario. E-mail:

Katrina.Longfield@uhn.on.ca

Andrea Warnick, RN, BScN, MA, Pediatric Grief

Counsellor, Max and Beatrice Wolfe Centre for Children's

Grief and Palliative Care, Toronto, Ontario

Please direct correspondence to Katrina J. Longfield 
children about the prognosis during a parent's illness and dying has been found to help the child's bereavement process (Christ, Siegel, Karus, \& Christ, 2005).

Nurses are often concerned that they do not have the necessary skills to support children and the adults around them through the process of watching a parent die. They also worry that they may do irreparable harm to the psyche of the child if they say the wrong thing (MacPherson, 2005). However, nurses need to know that the number of resources available to parents that address the topic of how to support their child through the dying and death of a parent is limited (Saldinger, Cain, Porterfield, \& Lohnes, 2004; Lohan, 2006). Thus, parents often look to the oncology nurse for guidance and direction on how to talk with their children about the parent's illness and impending death.

\section{A nursing narrative}

Sara was a 37-year-old woman admitted to an inpatient palliative care unit (PCU) in Toronto. Sara had a particularly aggressive form of breast cancer, and despite receiving radiation therapy and four different lines of chemotherapy, 10 months after being first diagnosed Sara was admitted to the PCU actively dying. Sara arrived on the unit not verbally responsive and with a life expectancy that could be measured in hours. Sara's brother and two sisters were with her. The PCU staff soon learned that Sara was the single mother of a fouryear-old boy named Jeremy who would be living with his uncle after his mother's death.

Initially, Sara's siblings were reluctant to bring Jeremy in to visit his mother. However, after I educated the family about the importance of providing Jeremy the opportunity to say goodbye to his mother and bringing to their attention the fact that Jeremy had been living with his mom and, thus, would have seen the changes that had occurred as his mother's cancer progressed, they did bring Jeremy in to see his mother that afternoon.

After receiving phone advice from Andrea Warnick, a children's grief counsellor, I went with Jeremy, one of his aunts, and his uncle into the quiet room on the PCU. I gave Jeremy a stuffed toy and spoke with him about his mom having breast cancer and that despite all the best efforts of the doctors and nurses, we were not able to get rid of the cancer and, because of this, the cancer would cause his mother to die. I explained that when a person died they stopped breathing, their heart stopped beating and that their body could no longer feel anything. I emphasized to Jeremy that nothing he had done or thought had caused the cancer and also reassured him that although his mother could no longer talk to him as she had a few days ago, she could still hear him and it was okay to talk to her and say he loved her.

At the end of this conversation, there was a dramatic change in this young boy's demeanour. Jeremy now appeared to have a sense of purpose and, in a very determined manner, he left the quiet room and ran down the hallway to his mother's room where he sat at his mother's bedside and said loudly, "I love you, mommy."

Although I had been working as a staff nurse at the bedside for 17 years, this was the first time I had had this type of conversation with the young child of a patient who was dying. I felt inadequately prepared, afraid that I would say the wrong thing, or forget to include some important element. However, I was aware of the fact that Jeremy's aunt and uncle were seeking guidance on how to support Jeremy as their sister approached death. It was extremely powerful to see the way Jeremy grasped the concept that his mother was dying and ran to her bedside.

\section{Talking to children about a parent's impending death}

The first step in talking to a child about a parent's impending death, for both parents and nurses, often involves becoming comfortable with one's own discomfort. Having such conversations with children is unfamiliar territory for most people, thus it is natural to feel anxious about entering into such a dialogue. Learning new skills involves pushing oneself outside of one's comfort zone.

It is ideal for the news of a parent's dying to come from a parent or caregiver who is close to the child. Nurses can play a central role in guiding parents on how to do this and, at times, will even need to facilitate the conversation directly with the child of a dying patient. In these cases, it is still important for at least one of the child's caregivers to be present to provide comfort to the child, and to be aware of what the child has been told.

Children of different developmental levels have varying abilities to understand concepts involving cancer and death. Yet, children of all ages react to the separation of a parent and benefit from having cancer and death described to them in clear, concrete, language. Regardless of age, some children will want more information than others.

\section{General considerations}

- Talk early. It should be part of the oncology nurse's standard of practice to encourage parents to talk to their children about a parent's potential or probable dying as soon as possible. The more time that passes in which the parent's prognosis is not discussed, the more the child has learned not to talk about it, and the greater the chance that the child will overhear the information somewhere. Whenever possible, the news of a parent's dying should come from one or both parents.

- Be honest. Adults often try to protect children by withholding information from them. However, children are able to sense when something is wrong in the family and often know when information is being withheld. When they are not being told what is happening around them, their anxiety often increases and they may use their imaginations to invent explanations for the situation. These explanations are often inaccurate and can cause the child to experience far more anxiety than the truth itself would elicit. Furthermore, a child's trust in his/her parent can be jeopardized if the child knows the parent has a history of withholding the truth. Reassure the child that he/she will be included in what is happening and that information will not be hidden from him/her.

- Don't be afraid to say, "I don't know". When discussing cancer and death with kids, they will likely have many questions for which there are no answers. Some may be answerable in time, while others may be inexplicable. As much as adults want to provide children with all the answers to their questions, it is important to teach children that there are some questions in life that do not have answers, but it is still good to wonder about these questions, and wondering out loud together can be better than wondering by oneself. For example, when asked why a parent got cancer, one could respond: "We don't know why mom/dad got cancer, but what we do know is that it is not anyone's fault. It isn't mom's fault, or dad's fault, or your fault. It isn't a punishment for doing anything wrong. Some things in life are a mystery and we don't have answers for them". The word "mystery" can be very helpful in discussing life's unknowables with kids.

- Children grieve in chunks. The way in which children grieve is different from how adults grieve. Children will often play very soon after being told of a parent's impending or actual death. This does not mean that they are not grieving. Rather, it is their way of regulating their emotions. Children also use play as a way to process their grief. Children have a wonderful capacity to hold deep sorrow and deep joy simultaneously.

\section{Conversation guidelines}

- Create the environment. Choose a place that is comfortable and where distractions will be minimized. Get down on the same eye level with the child. Younger children may find comfort in holding a stuffed animal. 
- Start by asking what they know about the situation so far. If they use any medical terminology, including the word "cancer", ask them to explain what those words mean. This provides the opportunity to clarify any misconceptions.

- Use the word "cancer". It is common for parents to avoid using the word cancer by instead referring to the person as being "sick" or having an "illness". Unfortunately, this is confusing for children. When the child or anyone else gets "sick", they'll worry that it could be the same sickness that the dying parent has and that they, too, could die from it. It is also good to name the type of cancer, and its origin. For example, "Mom has a disease called osteosarcoma. It is a type of cancer. It is a cancer of the blood cells."

- Reassure the child that the cancer is not contagious. Children often think that all illnesses can be spread from one person to the next such as a cold or the flu. Explain to them that cancer does not work this way-it is not something that can be "caught" from another person.

- Emphasize that the cancer is NOT anyone's fault. Adults often underestimate how responsible children feel for what is happening around them. If the child was angry with the parent, they may believe they caused the cancer to happen. Even if a child is not showing any signs of feeling responsible for the illness, it is important to let them know that nothing they did or thought caused the cancer.

- Describe the treatments that were used to try to cure the cancer. The child needs to know that every effort has been made to get rid of the cancer. "Chemotherapy" can be described as medicine that is used to treat cancer. Explain that sometimes it is given as a pill, and sometimes it is given through a tube, called an "IV", that goes into the parent's vein. Emphasize that everyone has tried really hard to get rid of the cancer, including the dying parent, but that sometimes the cancer is too strong for even the best medicines.

- Use the words "dying" and "dead". Explain that eventually the cancer will cause the body to stop working. That means the person will stop breathing, their heart will stop beating and their brain will stop working. That means the person can no longer think, hear, see, smell, taste or feel. Avoid euphemisms like "passed away" or "gone to a better place", which will only confuse a child. Do not refer to death as being like "sleep", as that can lead children to fear falling asleep. Also, to a child, phrases like "there's nothing more we can do" and "she/he's not going to get better" do not mean the same thing as "he/she's going to die."

- Tell the child who will take care of them. Although children may not vocalize it, when a parent is dying, one of a child's main concerns is 'Who will take care of me?' Even in two-parent families, children often become concerned about what would happen to them should the healthy parent die. Tell the child who will take care of them following the death. Also tell them the backup plan should that person die too. For example, "When your mom dies, your dad will take care of you. He will likely live a long time, but if something were to happen to him, then look after you."

- Explain that there are medicines for comfort. Children think of medicine as something people take to "get better". Clarify the difference between "palliative" and "curative" medicines, including palliative chemotherapy and palliative radiation. Explain that medications, such as morphine, are used to get rid of the pain, not to stop the dying.

- Ask the child if he/she wants to be told what changes to expect in the parent during the dying process. Some children want to know what to expect as soon as they learn of a parent's impending death, while others do not want to have this information until the parent is actively dying. If the child does want to know this information, explain the signs of approaching death in simple terms. Always tell the child what changes they will see in the parent, such as changes in the parent's appearance or pattern of breathing, before the child enters the room.

- Check in with the child frequently. Ask the child to explain in their own words their understanding of what you have told them. Try not to overwhelm them with too much information. Simply ask them if they want to know more information than what you have already provided them with.

- Encourage children to ask questions. Let children know that there are no questions that are out of bounds. Children who feel that they cannot ask their questions of the adults in their life will come up with their own, often inaccurate, explanations. Be prepared to repeat yourself as the child may ask the same questions over and over.

- Encourage families to grieve together. Adults often hide many of their emotions from children in an effort to protect them, but this only teaches children that emotions related to grief are to be contained or expressed alone. It is important for children to know that all of their feelings are okay, and that adults experience them too. Describe "grief" as all of the feelings people experience when someone is dying or has died. This includes being sad, mad, confused, lonely, and worried. Children learn how to grieve by watching the adults around them. Let families know that it is okay for them to cry together, be mad together, and be sad together.

\section{Conclusion}

It can be a heartbreaking experience for an oncology nurse to provide care to the dying parent of young children. Yet, by encouraging a model of open and honest communication within the family, nurses have an opportunity to play a powerful role in shaping the child's experience of the death and positively influencing their bereavement process. The ultimate goal for parents and nurses is not to protect children from adversity, but rather to provide them with the tools to prepare them for the windstorms of life.

\section{References}

Christ, G., Siegel, K., Karus, D., \& Christ, A. (2005). Evaluation of a bereavement intervention. The Journal of Social Work in Endof-Life and Palliative Care, 1(3), 57-81.

Kroll, L., Barnes, J., Jones, A.L., \& Stein, A. (1998). Cancer in parents: Telling children. British Medical Journal, 316, 880.

Lohan, J.A. (2006). School nurses' support for bereaved students: A pilot study. The Journal of School Nursing, 22(1), 48-52.

MacPherson, C. (2005). Telling children their ill parent is dying: A study of the factors influencing the well parent. Mortality, 10(2), $113-126$.

Riley, M. (2003). Facilitating children's grief. The Journal of School Nursing, 19(4), 212-218.
Robinson, C., \& Janes, K. (2001). "Is my mom going to die?" Answering children's questions when a family member has cancer. Canadian Oncology Nursing Journal, 11(2), 62-66.

Saldinger, A., Cain, A.C., Porterfield, K., \& Lohnes, K. (2004). Facilitating attachment between school-aged children and a dying parent. Death Studies 28, 915-940.

Silverman, P.R. (2000). Never too young to know: Death in children's lives. New York: Oxford University Press.

Smith, K., \& Boardman, K. (1995). Comforting a child when someone close dies. Nursing 95, 25(10), 58-59.

Welch, A.S., Wadsworth, M.E., \& Compass, B.E. (1996). Adjustment of children and adolescents to parental cancer. American Cancer Society, 77, 1409-1418. 